\title{
The Effect of E-Government Implementation on the Quality of Electronic Identity Card Public Service in Indonesia
}

\author{
Mansyur Achmad* \\ Masriadi Patu* \\ Ashariana Ashariana"* \\ https://doi.org/10.31297/hkju.21.2.3 \\ UDK \\ 35.755.61:004.3/4 \\ Original scientific paper / izvorni znanstveni rad \\ Received / primljeno: $\quad$ 04. 07. 2020. \\ Accepted / prihvaćeno: 09. 04. 2021.
}

This study examines the effect of e-government implementation on the quality of electronic identity card (EIC) public service in Takalar Regency. The research was conducted by using quantitative methods. The sample consisted of 300

* Mansyur Achmad, PhD, Senior Lecturer, the Pemerintahan Dalam Negeri Institute, Jakarta, Indonesia (viši predavač, Institut Pemerintahan Dalam Negeri, Jakarta, Indonesia, e-mail: mansyur.ipdn@gmail.com)

ORCID https://orcid.org/0000-0003-3929-570X

** Masriadi Patu, PhD, Senior Lecturer, Sekolah Tinggi Ilmu Administrasi Puangrimaggalatung Bone, Watampone, Indonesia (viši predavač, Visoka škola za upravne znanosti, Watampone, Indonezija, e-mail: masriadi.upri@gmail.com)

ORCID https://orcid.org/0000-0001-6977-052X

*** Ashariana Ashariana, Universitas Pejuang Republik Indonesia, Makassar, Indonesia (Sveučilište Pejuang Republike Indonezije, Makassar, Indonezija, e-mail: asharianayahya@gmail.com)

ORCID https://orcid.org/0000-0002-1414-9004 
employees and stakeholders who were selected by the iteration method. The data was collected via a Likert scale questionnaire and analysed with the path analysis technique. The independent variable was the e-government implementation, which consists of sub-variables: communication (X1), resources (X2), disposition (X3), and bureaucratic structure (X4). The dependent variable was the electronic identity card (EIC) service quality. The research findings indicate that the overall implementation of e-government has a significant effect on the quality of EIC service in Takalar Regency. Furthermore, it has also found a very lengthy bureaucratic structure and complicated communication methods in the EIC service. However, the aspects of resources and disposition have been well implemented.

Keywords: e-government implementation, communication, resources, disposition, bureaucratic structure, public services

\section{Introduction}

The government's primary function is to take care of public affairs in the form of goods and services. Government is the institutional superstructure that interprets political processes into policies and legislation (Karavasilis, Vrana \& Zafiropoulus, 2016). Its main objective is to ensure that every community can fulfil its public interest. Thus, the government is essentially a public servant (Hoessein, 2009). Because the government is a public servant, it can use all the state's tools, the country's wealth, including the technology needed to ensure public services that benefit all citizens.

The quality of public services is intended to meet customer satisfaction. It is indicated by the level of compatibility between consumers' expectations and the quality of service they obtained (Lewis, 1993; Parasuraman Ganapathy \& Shirinzadeh, 2004; Zeithaml et al., 1990).

To meet public demands for quality public services, governments worldwide are developing e-government, i.e., the use of information and communication technology and the Internet to support their work processes. It is intended to improve the delivery of government services to citizens, businesses, and other government agencies 24 hours a day, seven days a week, and bring better governance (Alruwaie, El-Haddadeh \& Weerakkody, 2012; Panagis et al., 2008). 
Indonesia has been developing e-government to meet global trends. It is based on Presidential Instruction of the Republic of Indonesia Number 3 of 2003 dealing with National Policies and Strategies for E-Government Development, one of which is population administration services. In the 2013Law of the Republic of Indonesia Number 24 amending the 2006 Law of the Republic of Indonesia Number 23 on Population Administration, Article 1/14 stipulates that the Electronic Identity Card, (EIC) is an identity card equipped with a chip and that it represents the official identity card of the citizen issued by the government.

The government is obliged and responsible for organizing the administration of all population matters. Article 5 of the 2006 Law Number 23 on Population Administration regulates the EIC service. E-government in the form of EIC service has reached $97.21 \%$ by 20 January 2021 . However, the population data of approximately 5.38 million residents spread across five provinces, especially in Eastern Indonesia, have not been recorded yet. ${ }^{1}$

The residents of Takalar District complained about slow handling of EICs at the Takalar Population and Civil Registry Administration Office. Sofyan Gata wrote about it in the Facebook group "Kabar Takalar" and was widely commented on by dozens of netizens. He said that "at the file registration site, we were surprised because the officer said that later at the end of July, the EIC could be issued because materials for issuing EIC is not available." Ayatullah Rawatib, the secretary of Population Registration Service in Takalar, stated that "there are still 20,000 sheets of blank stock available. However, from June to July 2018, the government ran out of EIC moulded plastic films. That is the reason for the slow service." Besides, the damage to EIC printing equipment became the main obstacle. Ayatullah Rawatib reports "the government only has two EIC printers, one of the EIC printers was damaged, so the officers could use only one printer. Hopefully, in regional budget in 2018, there will be an additional budget for the procurement of new printing machines".

Based on the available data, this research's main theses are that e-government in EIC service has not been running optimally, and that the quality of EIC service is still lacking. The research intends to answer whether the

${ }^{1}$ Moreover, based on data of the Department of Population and Civil Registration, Population and Family Planning of South Sulawesi, the number of people who have not recorded EIC has reached 345,535 in South Sulawesi. Nevertheless, the number is claimed to be increasingly reduced from previous data, which reached 665,947 people as of October 2018 last. The recording coverage in South Sulawesi is 94.92 percent. It means that the remaining 345,535 inhabitants were not recorded. 
e-government implementation affects the quality of EIC public service in Takalar Regency.

The independent research variable is e-government, which consists of sub-variables communication (X1), resources (X2), disposition (X3), and bureaucratic structure (X4). The dependent variable (variable $\mathrm{Y}$ ) is the electronic identity card (EIC) service quality.

Based on these research variables, the research hypotheses are formulated as follows:

1. Communication has a positive effect on the quality of EIC public service in Takalar Regency (District),

2. Resources have a positive effect on the quality of EIC service in Takalar Regency,

3. The disposition has a positive effect on the quality of EIC service in Takalar Regency,

4. The bureaucratic structure has a positive effect on the quality of EIC public service in Takalar Regency.

\section{Theoretical Framework}

The modernization of government and public service systems continues to be carried out by every country, including Indonesia. The development of increasingly sophisticated information and communication technology has touched every aspect of life. Therefore, the implementation of an electronic government system is necessary. In Indonesia, the implementation of e-government was marked by the 2003 Presidential Instruction No. 3 concerning National Policies and Strategies for E-Government Development. This instruction states that e-government development is an effort to develop governance based on (using) electronics to effectively and efficiently improve the quality of public services.

Thus, e-government in Indonesia is a policy, and the implementation of e-government is policy implementation. As a policy, the implementation of e-government can be assessed using the variable implementation of policies (Edwards, 1980; Van Meter \& Van Horn, 1975).

According to Van Meter and Van Horn (1975), policy implementation is more successful if policy performance is evaluated. It is based on the belief that policy implementation requires certain standards and objectives, which are in turn used as a reference for evaluating performance. There- 
fore, policy performance is the level of achievement of policy standards and objectives. Policies in implementation require adequate resources in the form of funds or other incentives. Policy performance will be low if the funds needed are not available in sufficient amount. The availability of resources is closely related to the social, economic, and political conditions in which the policy is implemented.

Furthermore, Van Meter and Van Horn (1975) argued that all the factors above, from the formulation of standards and targets, to the effectiveness of communication, to resources, to socio-economic and political conditions would shape the attitudes of policy implementers. The more positive the implementer's attitude, the higher the chance of achieving implementation effectiveness. Cognition, neutrality, and objectivity of individual implementers greatly influence their response to all the factors mentioned earlier and is the cause of the success or failure of implementation. If the implementer does not understand the policy's objectives, especially if the value system that influences their attitude is different from the policy maker's value system, the implementation is not sufficient.

According to Edwards (1980), four elements must be considered in policy implementation: (1) communication, (2) dispositions, (3) resources, and (4) bureaucratic structure. This research is used to reduce the e-government implementation variable. The relationship between the four essential elements of policy implementation by Edwards (1980) is visualized in the following figure.

Figure 1. Basic elements of e-government implementation

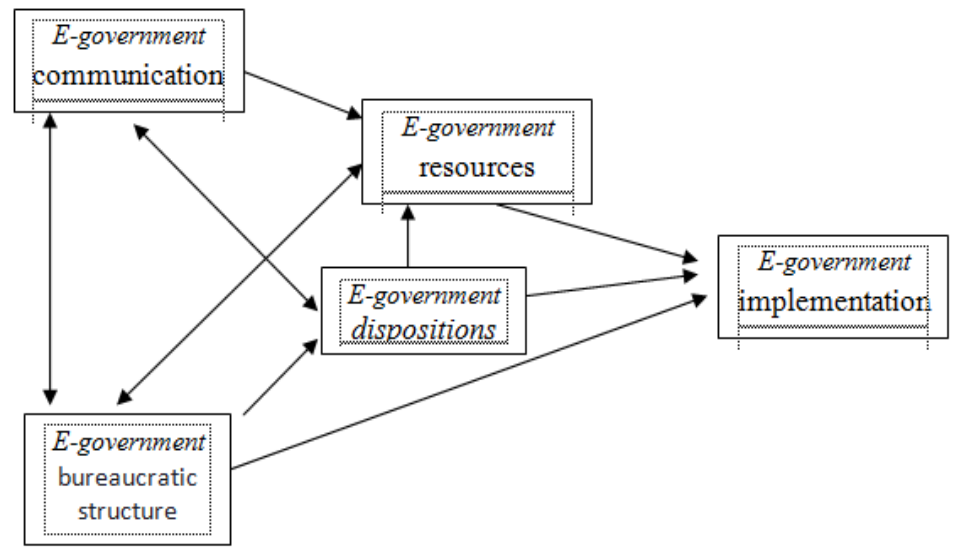

Source: Authors, based on modification from Edwards (1980). 
In line with Edwards' opinion, Grindle (1980) argues that the policy's content and context determine policy implementation effectiveness. Thus, after transforming a policy into an action program or individual project and preparing the costs, its implementation depends on the contents and context of the policy itself. Grindle (1980) explains that the content of policies affects their implementation. The content includes the interests affected by the policy, the types of benefits to be generated, the degree of change desired, the policymaker's position, the programme implementer, and the resources deployed. The context of implementation encompasses the power, interests, and strategies of the actors involved, the characteristics of institutions and mastery, compliance, and responsiveness.

Specifically, Kusnadi (2015) researched the implementation of healthcare policies in hospitals by developing a policy implementation variable from Edwards. He suggested that to determine public policy implementation indicators using Edwards' theory (1980), the sub-variables should consist of communication, resources, disposition, and bureaucratic structures. This study also uses this variable because the implementation of e-government is the implementation of a public policy.

Thus, the implementation of e-government is essentially the use of information and communication technology and the Internet to support the work processes of institutions and public service officers to improve public service quality for citizens, businesses, and even for other government institutions, without recognizing the time and place limits and with an impact on governance improvement (Alruwaie, El-Haddadeh \& Werakkody, 2012). Meier and Terán (2012) note that electronic government, or e-government, simplifies and executes information, communication, and interchanges processes within and between governmental institutions and between the governmental institutions and citizens or organizations. Additionally, Abu-Shanab (2014) reveals that e-government is a new phenomenon that improves public services provided to citizens, betters public sector performance, and enriches the political arena. E-government contributes to citizens' satisfaction by offering precise and quality information and a stable and convenient service (Fan \& Yang, 2015). Therefore, e-government is defined as providing public services through convenient online channels (Abu-Shanab, 2014).

The implementation of e-government in various countries has proven to reduce corrupt practices, increase transparency, reduce operational costs, and improve service quality. Several research results have shown significant correlations between e-government and reducing corruption (AbuShanab, 2017), better transparency (Khasawneh \& Abu-Shanab, 2013), 
and reducing operational costs (West, 2004). Therefore, the implementation of e-government is predominantly aimed at improving the quality of public services.

The concept of service quality (Zeithaml et al., 1990) provides clear and measurable indicators about which aspects of service are important. Each expert and researcher later modified the concept and dimensions of service quality developed by Parasuraman in accordance with their scientific development perspective and needs. Therefore, service quality can be "the difference between customer expectations from the service and perceived service. If expectations are greater than performance, the perceived quality is less than satisfactory, and hence customer dissatisfaction occurs" (Zeithaml et al., 1990).

Lewis (1993), Parasuraman et.al. (2004) said that there are five indicators in measuring the quality of public services:

- Tangibles consist of physical facilities, equipment, and appearance of personnel.

- Reliability is the ability to perform the promised service dependably and accurately.

- Responsiveness is a willingness to help customers and provide prompt service.

- Assurance includes competence, courtesy, credibility, and security. It is the knowledge and courtesy of employees and their ability to inspire trust and confidence.

- Empathy includes access, communication, and understanding of the customer. It is the caring and individualized attention that the firm provides to its customers.

Zeithaml (1990) argued in support of this that there are ten dimensions that must be considered while looking at the benchmarks of the quality of public services:

a. Tangible consists of physical facilities, equipment, personnel, and communication.

b. Reliable consists of the ability of service units to create the promised service appropriately.

c. Responsiveness is a willingness to help consumers take responsibility for the quality of services provided.

d. Competence is the demands it has, and good knowledge and skills of the apparatus in providing services. 
e. Courtesy is attitude or behaviour that is friendly and responsive to customers' desires and willingness to make contact or personal relationships.

f. Credibility is an honest attitude in every effort to attract public trust.

g. Security means that the services provided must be free from various dangers and risks.

h. Access means it is easy to make contact.

i. Communication is the willingness of service providers to listen to the voice, curiosity, or aspirations of customers, as well as the availability to convey information to the public.

j. Understanding the customer means that one makes every effort to find out the customer's needs.

In general, in the public service management literature, service quality is defined as intention to achieve customer satisfaction. It is even said that the quality of service is related to consumer satisfaction, which is indicated by the level of compatibility between consumers' expectations and what they get from public service (Grönroos, 1984; Lewis, 1993; Parasuraman Ganapathy \& Shirinzadeh, 2004; Zeithaml et al., 1990). Various service quality models were developed from this definition in order to increase customer satisfaction. One of them is the service quality model developed by Grönroos (1984).

Different perspectives in seeing the quality of public services show that the indicators used to compile public services quality vary. The various parameters used to measure the performance of public services can be grouped into two approaches. The first approach looks at the quality of public services from the perspective of service providers and the second approach from the perspective of service users. The division of approaches or perspectives in measuring public services' performance should not be seen as diametrically opposite but should still be understood as a viewpoint that interacts between the two. It is because the quality of public services is affected by various factors reciprocally. Environmental interactions can have a particular influence that can affect how the bureaucracy views the public and vice versa.

\section{Research Method}

This research was conducted by directly involving ten volunteers. The research method used was the quantitative method. The sample determina- 
tion was based on statistical calculations made by using the simple random sampling (SRS) technique. The researchers used stratification sampling to determine the number of samples in each existing population. To determine the population's size, the researchers used the proportional sampling technique (Al Rasyid, 2000). Before determining the respondents, the researchers first calculated the minimum number of samples using repeated calculation techniques (iteration) (Al Rasyid, 2000). The technique for determining the minimum sample size was used because it was suitable for a relatively large population with a high degree of heterogeneity. After applying the sampling technique, the minimum sample size was 169 . However, in this study, the number of samples taken was 300 out of 5,220 total population. The minimum sample size is believed to be representative of the entire population. The total population can be seen in the following table:

Table 1. The number of research population

\begin{tabular}{|c|c|c|c|c|}
\hline \multirow{2}{*}{ No } & \multirow{2}{*}{ Institution } & \multicolumn{2}{|c|}{ Sex } & \multirow{2}{*}{ Total } \\
\hline & & Male & Female & \\
\hline 1. & Government Employees & 2.163 & 3.017 & 5.180 \\
\hline 2. & $\begin{array}{l}\text { Regional Representatives } \\
\text { Council Member }\end{array}$ & 22 & 8 & 40 \\
\hline \multicolumn{2}{|c|}{ Total } & 2.185 & 3.025 & 5.220 \\
\hline
\end{tabular}

Source: Authors.

Data analysis and hypothetical testing were carried out using the path analysis (Al Rasyid, 2000). By path analysis, we intended to find out the degree of influence the $\mathrm{Xi}$ variable has on the $\mathrm{Y}$ variable, both directly and through the $\mathrm{Xj}$ variable, and the effect of all $\mathrm{X}$ variables together on the $\mathrm{Y}$ variable (Al Rasyid, 2000).

\section{Results and Discussion}

Quantitative analysis was used to determine the relationship of influence between e-government communication, e-government resources, e-government disposition, and e-government bureaucratic structure, analysed through testing the overall testing coefficient, direct and indirect influence, overall influence, and the influence of other variables that are not examined. 
The following statistical hypothesis is formulated to test the overall effect of variable $\mathrm{X}$ on $\mathrm{Y}$.

$$
\begin{aligned}
& \mathrm{H}_{0}: \mathrm{p}_{\mathrm{yx} 1}=\mathrm{p}_{\mathrm{yx2} 2}=\mathrm{p}_{\mathrm{yx} 3}=\mathrm{p}_{\mathrm{yx} 4}=0 \text { is rejected } \mathrm{H}_{0} \text {, if } \mathrm{f}_{\text {count }}<\mathrm{f}_{\text {table }} \\
& \mathrm{H}_{1} \text { : there is at least one } \mathrm{p}_{\mathrm{yx} 1} \neq 0 \text { is accepted } \mathrm{H}_{1} \text { if } \mathrm{f}_{\text {count }}>\mathrm{f}_{\text {table }}
\end{aligned}
$$

Table 2. Path significance coefficient test

\begin{tabular}{|c|c|c|c|}
\hline F-hit & 6.705058 & F-tab, $0.05 ; \mathrm{df}: 4$ & 2.4200 \\
\hline
\end{tabular}

Overall Test

Source: Authors.

Decisions are significant at the 95\% reliability level. The conclusion is that at least one PYX1, X2, X3 and X4 is not the same.

Based on the overall coefficient test with a significance level of $95 \%$, the path coefficients (pyxi) X1, X2, X3, and X4 to Y were 0.2100, 0.2195, and 0.2050 , respectively. Based on the overall coefficient testing with the level of significance of $95 \%$, the path coefficients (pyxi) X1, X2, X3, and $\mathrm{X} 4$ to $\mathrm{Y}$ were $0.2100,0.2195$, and 0.2050 , respectively. Additionally, the F-count was 6.705058, which was greater than the F-table (2.4200). It means that the variable of communication (X1), resources (X2), disposition (X3), and bureaucratic structure (X4) simultaneously and significantly influenced the quality of EIC public service.

On the other hand, the relationship between the four variables $\mathrm{X} 1, \mathrm{X} 2$, $\mathrm{X} 3$, and $\mathrm{X} 4$ with variable $\mathrm{Y}$ can also be studied individually through the correlation matrix between variables. Moreover, the relationship between one variable and the other(s) shows the correlation between variables. It is illustrated in the matrix correlation table below.

Table 3. Correlation matrix between variables

\begin{tabular}{|c|c|c|c|c|}
\hline $\mathrm{X} 1$ & $\mathrm{X} 2$ & $\mathrm{X} 3$ & $\mathrm{X} 4$ & $\mathrm{Y}$ \\
\hline 1.0000 & 0.8067 & 0.9270 & 0.6034 & 0.7208 \\
\hline 0.8067 & 1.0000 & 0.8055 & 0.4095 & 0.7176 \\
\hline 0.9270 & 0.8055 & 1.0000 & 0.5629 & 0.7075 \\
\hline 0.6034 & 0.4095 & 0.5629 & 1.0000 & 0.4241 \\
\hline 0.7208 & 0.7176 & 0.7075 & 0.4246 & 1.0000 \\
\hline
\end{tabular}

Source: Authors 
Table 1 shows that the correlation between the variables $\mathrm{X} 1$ and $\mathrm{X} 2$ is 0.8076 . The correlation between $\mathrm{X} 2$ and $\mathrm{X} 3$ is 0.8064 . The correlation between $\mathrm{X} 3$ and $\mathrm{X} 4$ is 0.5629 . The correlation between $\mathrm{X} 1$ and $\mathrm{X} 3$ is 0.9274 , the correlation between X2 and X4 is 0.4104 , and the correlation between $\mathrm{X} 1$ and $\mathrm{X} 4$ is 0.6048 . The results show that the correlation between the independent variables is positive and significant.

Communication (X1): According to the results of statistical analysis performed by the path analysis method, we can explain the influence of EIC communication variables on the quality of EIC public service. Variable X1 (e-government communication) positively affects variable Y (EIC public service quality). After calculating and testing the data, the path coefficient X1 (communication) to Y (quality of EIC public service) is 0.2889 . Therefore, the direct effect of $\mathrm{X} 1$ on $\mathrm{Y}$ is $8.13 \%$. Furthermore, the influence of X1 (communication) through the factors X2 (resources), X3 (disposition), and $\mathrm{X} 4$ (bureaucratic structure) is $12.87 \%$. Therefore, the total effect of $\mathrm{X} 1$ on $\mathrm{Y}$ is $21.00 \%$.

To test the effect of X1 (communication) on Y (quality of public service e-KTP), a research paradigm was formulated:

$$
\begin{array}{ll}
\mathrm{H}_{0}: \text { pyxi } \leq 0 ; & \text { rejected } \mathrm{H}_{0}=\text { if } \mathrm{t}_{\text {count }}<\mathrm{t}_{\text {table }} \\
\mathrm{H}_{1}: \text { pyxi }>0 ; & \text { accepted } \mathrm{H}_{1}=\text { if } \mathrm{t}_{\text {count }}>\mathrm{t}_{\text {table }}
\end{array}
$$

Table 4. Individual Testing

\begin{tabular}{|l|r|r|}
\hline T-YX1 & 11.61589 \\
\hline
\end{tabular}

Source: Authors.

Decisions are significant at the $95 \%$ reliability level. Conclusion Ho is rejected and $\mathrm{Hi}$ is accepted or X-1 affects $\mathrm{Y}$.

Based on the results of statistical tests on the pyx 1 path at the level of significance $95 \%$ with $\alpha=0.05$, $t$ count is 11.61589 , and $t$ table is 2.9600 . Because the $t$ count is greater than the $t$ table, H0 is rejected, and $\mathrm{H} 1$ is accepted. Thus, it can be concluded that at the level of $5 \%$, the variable $\mathrm{X} 1$ (communication) has a significant positive effect on Y (quality of EIC public service).

The test results have shown that although the communication variable is a factor that influences the quality of EIC public service, it is not the dominant factor. Communication will further determine the quality of EIC public service in e-government implementation if the variable of resourc- 
es, disposition, and bureaucratic structure improves as well. It is shown by the results of statistical calculations of the amount of influence of variable $\mathrm{X} 1$ on other variables.

The influence of communication variables on resource variables is $11.37 \%$, on the disposition variable $1.45 \%$, and on the bureaucratic structure $0.05 \%$. It means that communication will run well if supported by the availability of resources, by implementor's disposition, and by the bureaucratic structure. The better the communication, the higher the quality of the EIC public service.

The statistical test results explain that each improvement in the communication variable makes the EIC public service better on the condition that other variables improve. The results of this study are in line with the results of previous research (Khasawneh \& Abu-Shanab, 2013; AbuShanab, 2017) which has shown that the implementation of e-government in various countries has proven successful in improving the quality of public services. In addition, government-citizen communication is key to e-government (Berger, Hertzum \& Schreiber, 2016).

It confirms the theory of Parasuraman, Berry, and Zeithaml, (1985) regarding the quality of public services, which was further developed by Parasuraman Ganapathy, and Shirinzadeh in 2004. The theory states that one of the indicators of the quality of public services is the service provider's ability to communicate. This study has also found that communication via information technology is more effective than conventional communication.

Resources (X2): Based on the results of statistical analysis performed by the path analysis method, the calculation of the path coefficient X2 (resources) to Y (quality of EIC public service) is 0.3754 . Therefore, the rate of direct influence of $\mathrm{X} 2$ on $\mathrm{Y}$ is $14.10 \%$. Furthermore, the cumulative influence through factors X1 (communication), X3 (disposition), and X4 (bureaucratic structure) is $21.95 \%$.

To examine the effect of variable X2 (Resources) on Y (quality of EIC public service), a research paradigm was formulated:

$$
\begin{aligned}
& \mathrm{H}_{0}: \text { pyxi } \leq 0 ; \quad \text { rejected } \mathrm{H}_{0}=\text { if } \mathrm{t}_{\text {count }}>\mathrm{t}_{\text {table }} \\
& \mathrm{H}_{0}: \text { pyxi }>0 ; \quad \text { accepted } \mathrm{H}_{1}=\text { if } \mathrm{t}_{\text {count }} \leq \mathrm{t}_{\text {table }}
\end{aligned}
$$

Table 5. Individual testing

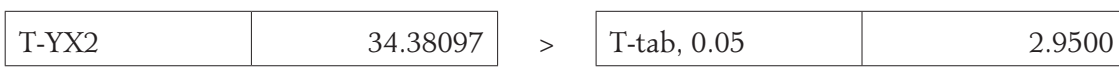

Source: Authors. 
Decisions are significant at the 95\% reliability level. Conclusion Ho is rejected and Hi accepted or X-2 affects Y.

Based on the statistical test on the PYX2 line at the significance level $95 \%$, with $\mathrm{a}=0.05$, $\mathrm{t}$ count is 34.38097 , while $\mathrm{t}$ table is 2.9600 . Because the $t$ count is greater than the $\mathrm{t}$ table, $\mathrm{H} 0$ is rejected, and $\mathrm{H} 1$ is accepted. Thus, it can be concluded that at a significant level of $5 \%$, the variable X2 (e-government resources) has a positive effect on Y (quality of EIC public service).

After statistical calculations using path analysis, the hypothesis is accepted, where the test results obtained are $21.95 \%$. It also means that, although resources are a factor that influences the quality of EIC public service, it is not the dominant factor. The resources variable will determine EIC public service quality if the communication, disposition, and bureaucratic structure variables are improved and more supportive.

In detail, it can be explained that the effect of resources on communication variables is $6.56 \%$. It means that the better the relationship between communication and resources, the better the quality of e-KTP public service. The effect of resources variable on the disposition variable is $1.26 \%$, which means that the better the disposition, the higher the influence of resources on EIC public service's quality. Moreover, the influence of resource variable on e-government bureaucratic structure variable is only $0.03 \%$. The data proves that the bureaucratic structure has minimal impact on the quality of public e-KTP service. Therefore, things that must be considered concerning the influence of resource variable on EIC public service' quality are communication and disposition variables. Another interpretation that emerges from the results of this study shows that the allocation of resources for e-government in EIC service requires intensive socialization and support for the attitudes of implementers or government officials, both central and regional.

The cumulative influence of resources on other variables is $7.85 \%$. The data prove that the better the relationship between resource and communication variables, disposition, and bureaucratic structure, the better the EIC public service quality in Takalar Regency. The results of this study align with Van Meter and Van Horn's ideas (1975), who connect more successful implementation with policy performance achievements. It is also supported by Grönroos' (1984) view that the quality of public services is determined by consumer satisfaction with the availability of service resources. Zeithaml's (1990) theory has been proven as he formulates that one of the factors of public service quality is competence and understand- 
ing of the customer. However, this study has found that these factors cannot stand alone but depend on other factors.

Disposition (X3): Based on the results of statistical analysis performed by the path analysis method, we can explain the effect of disposition on the quality of EIC public service. After calculating and testing the data, the result of path coefficient X3 (disposition) to Y (quality of EIC public service) is 0.191 . Therefore, the direct effect of $\mathrm{X} 2$ on $\mathrm{Y}$ is $1.56 \%$, and the cumulative influence on the variables X1 (Communication), X2 (resources), and X4 (Bureaucratic Structure) is 20.50\%.

To test the effect of variable X3 (disposition) on variable Y (quality of e-KTP public service) a research paradigm was formulated:

$$
\begin{aligned}
& \mathrm{H}_{0} \text { : pyxi } \leq 0 ; \quad \text { rejected } \mathrm{H}_{0}=\text { if } \mathrm{t}_{\text {count }}<\mathrm{t}_{\text {table }} \\
& \mathrm{H}_{0} \text { : pyxi }>0 ; \quad \text { accepted } \mathrm{H}_{1}=\text { if } \mathrm{t}_{\text {count }}>\mathrm{t}_{\text {table }}
\end{aligned}
$$

Table 6. Individual testing

\begin{tabular}{|l|r|r|}
\hline T-YX3 & 4.736572 \\
\hline
\end{tabular}

Source: Authors.

Decisions are significant at the $95 \%$ reliability level. Conclusion Ho is rejected and Hi is accepted or X-3 affects Y.

The statistical test on the PYX3 path at the level of significance 95\%, with $a=0.05 t$ count is 4.4736572 , and $t$ table is 2.9600 . Because the $t$ count is greater than the $\mathrm{t}$ table, $\mathrm{H} 0$ is rejected, and $\mathrm{H} 1$ is accepted. Thus, it can be concluded that at a significant level of 5\%, the disposition (X3) has a positive effect on Y (quality of EIC public service). This study has found that by using statistical data analysis and testing the proposed hypothesis, we can accept that the disposition variable affects the quality of EIC public service.

After statistical calculations performed by path analysis, the hypothesis is accepted, and the test results obtained are $20.50 \%$. It means that the disposition variable is a factor that influences the quality of e-KTP public service but is not the dominant factor.

Based on the test results obtained via path analysis, the direct effect of disposition variable on the quality of EIC public service is only $1.56 \%$. Meanwhile, the effect of disposition (X3) on resources (X2) is $11.35 \%$, on communication (X1) is $7.54 \%$ and on variable X4 (e-government bureaucratic structure) $0.04 \%$. The effect of disposition (X3) on resources 
(X2) is $11.35 \%$, on communication (X1) is $7.54 \%$, and on the bureaucratic structure (X4) is $0.04 \%$. It proves that the attitude of e-government policy implementers will determine the quality of EIC public service if the communication, resources, and bureaucratic structures are improved and supportive. This study's results are in line with the findings of Zeithaml and his colleagues (1990), which they call the courtesy and credibility factor, and of Grönroos (1984), who calls it the attitudes factor. It is also in line with Meier and Terán's (2012) findings, who call it interchange processes. However, it is different from Grindle's (1980) finding which suggests that the effectiveness of policy implementation is determined by the content and context of the policy.

This study's results imply that implementers' attitude will be right if their abilities are reinforced by supporting facilities and infrastructure. A professional and proportional reward system and intensive socialization and unified communication between superiors and subordinates and among subordinates themselves is also essential.

Bureaucratic structure (X4): Based on the results of statistical analysis performed by using the path analysis method, we can explain the effect of the e-government bureaucratic structure on the quality of EIC public service. After calculating and testing the data, the path coefficient for the bureaucratic structure $(\mathrm{X} 4)$ for the quality of EIC public service $(\mathrm{Y})$ is 0.0280 . Therefore, the direct effect of $\mathrm{X} 4$ on $\mathrm{Y}$ is $0.08 \%$, and the total effect on variables $\mathrm{X} 1$ (communication), $\mathrm{X} 2$ (resources), and $\mathrm{X} 3$ (disposition) is $11.64 \%$.

To test the effect of the bureaucratic structure (X4) on the quality of EIC public service $(\mathrm{Y})$, a research paradigm was formulated:

$$
\begin{aligned}
& \mathrm{H}_{0}: \text { pyxi } \leq 0 ; \quad \text { Rejected } \mathrm{H}_{0}=\text { if } \mathrm{t}_{\text {count }}<\mathrm{t}_{\text {table }} \\
& H_{0}: \text { pyxi }>0 ; \quad \text { accepted } H_{1}=\text { if } t_{\text {count }}>t_{\text {table }}
\end{aligned}
$$

Table 7. Individual testing

\begin{tabular}{|l|r|r|}
\hline T-YX4 & 4.999225 \\
\hline
\end{tabular}

Source: Authors.

Decisions are significant at the $95 \%$ reliability level. Conclusion Ho is rejected and Hi is accepted or X-4 affects Y.

Based on the statistical test on the PYX4 line at the significance of 95\%, with alpha $=0.05$, the $t$ count is 4.9992 , while the $t$ table is 2.9600 . Be- 
cause $\mathrm{t}$ count is greater than $\mathrm{t}$ table, $\mathrm{H} 0$ is rejected and $\mathrm{H} 1$ is accepted. Thus, it can be concluded that at a significant level of $5 \%$ bureaucratic structure (X4) has a positive effect on the quality of EIC public service (Y).

These results mean that the bureaucratic structure is a variable that influences and determines the quality of public EIC service in Takalar Regency. However, as with other variables, the bureaucratic structure variable will determine the quality of the e-KTP public service to a greater degree if the communication, resource, and disposition variables are also improved. It is shown through the calculation and test results of the influence of the bureaucratic structure variable on other variables. The influence of bureaucratic structure on communication variable is $4.91 \%$, on resource variable is $5.77 \%$, and on disposition, variable is $0.88 \%$. Thus, the influence of the bureaucratic structure on the variable quality of public service EIC in comparison to the other variables is $11.64 \%$.

The study's results support Edwards' theory (1980), which places bureaucratic structure as the last variable after communication, resources, and disposition as variables that affect the quality of EIC public service in the implementation of e-government policies. The results imply that the bureaucratic structure should be decentralized in accordance with the optimal use of information and communication technology and the internet as the main instruments of e-government. Thus, it will have an impact on the formation of a public service bureaucratic structure as well as on improving governance (Karavasilis, Vrana \& Zafiropoulus, 2016) regardless of time and place limits.

Variables X1, X2, X3, X4: After consecutive discussion and analysis of the four $X$ variables (implementation of e-government) and their effect on $\mathrm{Y}$ (quality of public service E-KTP), the influence the overall $\mathrm{X}$ variables have on variable $\mathrm{Y}$ is easily visible. The influence of the relationship between the four variables of e-government policy implementation -communication, resources, disposition, and bureaucratic structure - on the quality of EIC public service is explained. Furthermore, the discussion has theoretically and empirically studied the factors that affect the quality of EIC public service and linked them to research results on e-government and public services previously obtained by research institutions and individuals. 
Table 8. Total Influence of $X$ on $Y$

\begin{tabular}{|c|c|c|c|c|c|c|c|}
\hline & \multirow{2}{*}{$\begin{array}{c}\text { Direct } \\
\text { Influence }\end{array}$} & \multicolumn{4}{|c|}{ Indirect influence through } & \multirow{2}{*}{$\begin{array}{c}\text { Sub- } \\
\text { Total }\end{array}$} & \multirow[t]{2}{*}{ Total } \\
\hline & & $\mathrm{X}-1$ & $\mathrm{X}-2$ & $\mathrm{X}-3$ & $\mathrm{X}-4$ & & \\
\hline$X-1$ & 0.0813 & & 0.1137 & 0.0145 & 0.0005 & 0.2100 & $21.00 \%$ \\
\hline $\mathrm{X}-2$ & 0.1410 & 0.0656 & & 0.0126 & 0.0003 & 0.2195 & $21.95 \%$ \\
\hline$X-3$ & 0.0156 & 0.0754 & 0.1135 & & 0.0004 & 0.2050 & $20.50 \%$ \\
\hline $\mathrm{X}-4$ & 0.0008 & 0.0491 & 0.0577 & 0.0088 & & 0.1164 & $11.64 \%$ \\
\hline \multicolumn{7}{|c|}{ Total influence of X on Y } & $75.08 \%$ \\
\hline \multicolumn{7}{|c|}{ The influence of other variables (not studied) (E) } & $24.92 \%$ \\
\hline
\end{tabular}

Source: Authors.

Figure 3. Research paradigm patbways

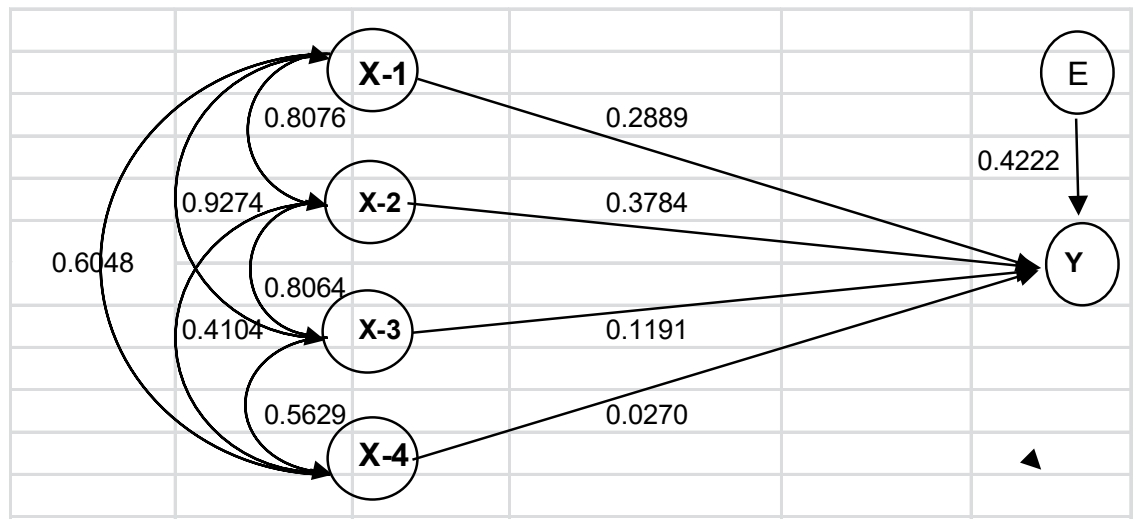

Source: Authors.

Table 3 and the image of the research paradigm path show that the four existing variables are consecutively used as factors that affect the quality of EIC public service. The resources variable has moderate influence and is not a dominant factor. Based on the calculation of path analysis, this variable contributes $21.95 \%$. The next variable is the communication variable, which contributes $21.00 \%$. The disposition variable has an influence on the $\mathrm{Y}$ variable by $20.50 \%$. Finally, the bureaucratic structure variable influences $11.64 \%$.

The study has shown that there are no dominant variables that affect the quality of EIC public service. However, it can be seen that the varia- 
ble with the most significant contribution is the resource variable. The percentage of respondents' answers to the resource variable items shows the rate of $64.24 \%$. The resources variable encompasses the budget, the people, the facilities and infrastructure, the technology, the information systems, and the networks. Adequate budget allocation, the inclusion of extension workers and assistants, and provision of supporting facilities and infrastructure for improving the quality of EIC public service, both from the central and regional governments, considerably determine the effectiveness of implementation of the EIC public service in Takalar Regency. It is a factor that has the most significant influence on the quality of EIC public service.

The variable that has the second most significant influence of $21.00 \%$ is the communication variable, with an average respondent's feedback of $67.75 \%$. The communication variable consists of the following indicators: the mechanism of central and regional relations, the relationships between superiors and subordinates and other informal communication channels, the elements of clarity of rules and regulations, the clarity of procedures, the clarity of leadership and the clarity of values of flexibility, and the elements of consistency - rules, and regulations, consistency of procedures and consistency of implementation standards. These elements reflect the government's political will and transparency in implementing e-government policies, especially EIC public service.

The contribution of the disposition variable and bureaucratic structure is $20.50 \%$ and $11.64 \%$, respectively. This value does not mean that these two variables do not affect the e-government implementation, because based on the results of statistical tests, the effect is significant. These variables contain elements such as attitude, behaviour, and commitment of implementers in e-government policy programmes, including in carrying out EIC service activities.

The theory of Van Meter and Van Horn (1975), which claims that the achievement of policy performance influences the success of policy implementation, is in line with this study's findings. It is the same case with Edwards' theory (1980) of four factors that influence the success of public policy implementation, and Grindle's theory (1980), which claims that policy implementation is influenced by the content and policy context factors. The results of this study are also in line with research results presented by Abu-Shanab (2017). He has shown that there is a significant correlation between e-government and reducing corruption (Khasawneh \& Abu-Shanab, 2013), better transparency (Abu-Shanab, 2017), and re- 
ducing operational costs (West, 2004). This study has found some corrupt practices as well as a lack of transparency and slow service contributed to the inadequate management of communication, resources, disposition, and bureaucratic structure.

In line with the previous results (Lewis, 1993; Parasuraman, Ganapathy \& Shirinzadeh, 2004; Zeithaml et al., 1990), our research indicates that in this particular case the quality of service has not been maximized. The design of e-government bureaucracy in the EIC service is still too centralized with a very complex structure. Another finding is that there is no bureaucratic structure for EIC public service. It is formed without recognizing the time and place limits and does not impact improving governance (Karavasilis, Vrana \& Zafiropoulus, 2016).

\section{Conclusion}

After discussing the research results and testing hypotheses via specific methods and degrees of trust, we have come to the following conclusions. First, the implementation of e-government with communication sub-variables significantly influences the quality of EIC public service in Takalar Regency, Indonesia. Therefore, the implementation of e-government aimed at the quality of public services is determined by the intensity of socialization of e-government policies with various consequences for the entire community. It is evident from the results of testing the research hypothesis that e-government communication variables positively affect EIC public service quality. E-government implementation can improve the quality of EIC service if e-government policies continue to be communicated intensively through improved channels using the clear messages in a more decentralized manner.

Second, e-government implementation with resource sub-variable significantly influences the quality of EIC public service in Takalar Regency. Thus, the higher the allocation of EIC resources, money and other facilities, infrastructure, and supporting resources, the higher the quality of EIC public service in Takalar Regency. It can be proven by testing the hypothesis that resources positively affect the quality of EIC public service. It means that it is necessary to support sufficient and adequate e-government resources without corruption through a transparent system to improve the quality of EIC public service in Takalar. 
Third, the implementation of e-government with the disposition sub-variable significantly influences the quality of EIC public service in Takalar Regency. The disposition sub-variable, which encompasses attitudes and behaviour of the e-government policy implementors, or in this case, the population administration operator (government and local government), largely determines the quality of EIC public service. For this reason, the changes in attitudes and behaviour of the apparatus, from sectoral egos to joint work and teamwork, are directly proportional to the improvement of the quality of EIC public service. This conclusion was obtained by testing the hypothesis which states that the e-government disposition variable positively affects the quality of EIC public service. However, based on the test results, the influence of e-government disposition variable on the quality of EIC public service turned out to have a significant relationship with the e-government resource and communication variables. Disposition influences the quality of EIC service if it is supported by resource and communication variables.

Fourth, e-government implementation with the bureaucratic structure sub-variable significantly influences the quality of EIC public service in Takalar Regency. The e-government bureaucratic structure as a manifestation behaviour of both central and regional government organizations will significantly determine the procedures and processes of public accessibility of public services. The establishment of bureaucratic structure that accumulates the community's interests determines the quality of EIC public service. The test results show that the direct influence of the e-government bureaucratic structure on the quality of EIC public service is minimal. However, the e-government bureaucratic structure has a positive and significant influence on the quality of EIC public service through e-government resources, e-government communication, and disposition of government. Thus, no matter how good the government structure is, it will not develop unless it is supported by resource-government, communication-government, and the attitude of government officials.

\section{References}

Abu-Shanab, E. (2014). Antecedents of trust in e-government services: An empirical test in Jordan. Transforming Government: People, Process and Policy, 8(4), 480-499.

Abu-Shanab, E. A. (2017). E-government familiarity influence on Jordanians' perceptions. Telematics and Informatics, 34(1), 103-113. 
Al Rasyid, H. (2000). Statistik sosial [Social statistics]. Bandung, Indonesia: UNPAD.

Alruwaie, M., El-Haddadeh, R., \& Weerakkody, V. (2012). A framework for evaluating citizens' expectations and satisfaction toward continued intention to use e-government services. International Conference on Electronic Government, 273-286, https://doi.org/10.1007/978-3-642-33489-4_23

Berger, J. B., Hertzum, M., \& Schreiber, T. (2016). Does local government staff perceive digital communication with citizens as improved service? Government Information Quarterly, 33(2), 258-269. doi: https://doi.org/10.1016/j. giq.2016.03.003

Edwards, G. C. (1980). Implementing public policy. Washington, USA: Congressional Quarterly Press.

Fan, J., \& Yang, W. (2015). Study on e-government services quality: The integration of online and offline services. Journal of Industrial Engineering and Management, 8(3), 693-718, https://doi.org/10.3926/jiem.1405

Grindle, M. S. (1980). Politics and policy implementation in the Third World. New Jersey, USA: Princeton University Press, https://doi.org/10.1515/9781400886081

Grönroos, C. (1984). A service quality model and its marketing implications. European Journal of Marketing, 18(4), 36-44, https://doi.org/10.1108/ EUM0000000004784

Hoessein. (2009). Perubaban model, pola dan bentuk pemerintaban daerab dari era orde baru ke era reformasi [Changes in models, patterns and forms of regional government from the new order era to the reformation era]. DIA-FISIP UI Depok.

Karavasilis, I., Vrana, V. G., \& Zafiropoulos, K. (2016). An extended model of e-government adoption by civil servants in Greece. International Journal of Electronic Government Research (IJEGR), 12(1), 1-23, https://doi.org/10.4018/ IJEGR.2016010101

Khasawneh, R. T., \& Abu-Shanab, E. (2013). E-government and social media sites: The role and impact. World Journal of Computer Application and Technology, 1(1), 10-17, https://doi.org/10.13189/wjcat.2013.010103

Kusnadi, D. (2015). The influence of policy implementation from the change of institutional status toward quality of patient service in hospital. International Journal of Scientific \& Technology Research, 4(10), 159-164.

Lewis, B. R. (1993). Service quality measurement. Marketing Intelligence \& Planning, 11(4), 4-12, https://doi.org/10.1108/02634509310044199

Meier, A., \& Terán, L. (2012). E democracy \& e government. Switzerland AG: Springer Nature.

Panagis, P., Stergiopoulos, F., Marabeas, P., \& Manias, S. (2008). Comparison of state of the art multilevel inverters. 2008 IEEE power electronics specialists conference, 4296-4301, https://doi.org/10.1109/PESC.2008.4592633

Parasuman, A, Berry, L. L, \& Zeithaml, V. A. (1985). SERVQUAL: A multiple-item scale for measuring customer perceptions of service quality, Report No. 86-108. Cambridge, UK: Marketing Science Institute. 
Parasuraman, S., Ganapathy, V., \& Shirinzadeh, B. (2004). Behaviour based mobile robot navigation technique for real world environments using fuzzy logic system. 2004 IEEE International conference on systems, man and cybernetics (IEEE Cat. No. 04CH37583), 4, 3359-3364.

Van Meter, D. S., \& Van Horn, C. E. (1975). The policy implementation process: A conceptual framework. Administration \& Society, 6(4), 445-488.

West, D. M. (2004). E-government and the transformation of service delivery and citizen attitudes. Public Administration Review, 64(1), 15-27.

Zeithaml, V. A., Parasuraman, A., Berry, L. L., \& Berry, L. L. (1990). Delivering quality service: Balancing customer perceptions and expectations. New York, USA: Simon and Schuster.

\section{THE EFFECT OF E-GOVERNMENT IMPLEMENTATION ON THE QUALITY OF ELECTRONIC IDENTITY CARD PUBLIC SERVICE IN INDONESIA}

\section{Summary}

This study examines the effect of e-government implementation on the quality of electronic identity card (EIC) public service in Takalar Regency, South Sulawesi, Indonesia. The research was conducted by using quantitative methods. The sample consisted of 300 employees and stakeholders who were selected by the iteration method. The data was collected via a Likert scale questionnaire and analysed with the path analysis technique. The independent variable was the e-government implementation, which consists of sub-variables: communication (X1), resources (X2), disposition (X3), and bureaucratic structure (X4). The dependent variable was the electronic identity card (EIC) service quality. The research findings indicate that the overall implementation of e-government has a significant effect on the quality of EIC service in Takalar Regency, Indonesia. It has also found a very lengthy bureaucratic structure and complicated communication methods in the EIC service. The aspects of resources and disposition have been well implemented.

Keywords: e-government implementation, communication, resources, disposition, bureaucratic structure, public services 


\title{
UČINAK PRIMJENE E-UPRAVE NA KVALITETU USLUGE IZDAVANJA ELEKTRONIČKE OSOBNE ISKAZNICE U INDONEZIJI
}

\begin{abstract}
Sažetak
Ispituje se učinak primjene e-uprave na kvalitetu usluge izdavanja osobne iskaznice u okrugu Takalaru u regiji Južnom Sulawesiju, Indonezija. Istraživanje je provedeno korištenjem kvantitativnim metodama prikupljanja podataka. Uzorak obubvaća 300 zaposlenika i dionika koji su odabrani metodom iteracije. Podaci su prikupljeni upitnikom sa skaliranjem odgovora po Likertu te analizirani tebnikom analize puta. Nezavisna je varijabla primiena e-uprave, a sastoji se od podvarijabli komunikacije (X1), sredstva (X2), suradliivost (X3) $i$ upravna struktura (X4). Zavisna je varijabla kvaliteta usluge izdavanja osobne iskaznice. Rezultati istraživanja pokazuju da primjena e-uprave općenito bitno utječe na kvalitetu usluge izdavanja osobne iskaznice u okrugu Takalaru. Utvrdeno je $i$ postojanje iznimno dugotrajna upravnog postupka $i$ kompliciranih metoda komunikacije u izdavanju osobnib iskaznica. Sredstva $i$ suradljivost $u$ pružanju te usluge bili su primjereni.

Ključne riječi: primjena e-uprave, komunikacija, sredstva, suradljivost, upravna struktura, javne usluge
\end{abstract}

